\title{
Byzantium: Religion, Art, Architecture.
}

\author{
Arbela Kisi \\ University of Vlora, Ismail Qemali, Vlore, Albania \\ E-mail: arbelak@yahoo.com
}

\section{Doi:10.5901/ajis.2013.v2n8p194}

\begin{abstract}
Byzantium was theocratic empire with heterogeneous populations. The unifying factor to manage the politics, faith and national identity in the first place, as the best candidate, was religion. She was closely associated with the state. Religion was allied with the monarchy. The Glory of Byzantium is material and cultural heritage of humanity, which impresses with its richness and complexity.Luxury goods, rich decorated manuscripts, icons, works with engraving, ecclesiastical and liturgical decorated in gold and silver are important examples that stimulate the curiosity for the luxury of the byzantine religious culture. The majority of byzantine art was commissioned for religious purposes and predestined to be used in churches and monasteries. The churches could have three different types of clients-comittenti, not always easily distinguishable from each other: the state, the local church and private benefactors. The members of the imperial house and the courtyard were zealous patrons for buildings and works of religious art. The best example is the Hagia Sophia in Constantinople, built by Justinian.Byzantium has formed an image that is identified by the iconography (Christ, St. Mary, iconoclasm), mosaics (symbolism, techniques, naturalism), orthodox churches ( type, construction techniques). The Byzantine Empire is one of the great lost civilizations, with an extraordinary eternal culture.
\end{abstract}

Keywords: Byzantium, religion, politics, culture, heritage

\section{Introduction}

Bizanti was a multicultural state. Emphasis on language, not in ethnicity, as a symbol of culture, followed a precedent Roman tolerance. State - modern nation, was hiding in the future. Such as racial prejudice is not a feature of Byzantine culture. ( Cameron, Bizantinet, 2008:31) Byzantine prejudices existed, but they had other directions.

The term Byzantine Emperor, is a definition of modern historiography. In reality there was never a state to define in this way. There was in fact the Roman Empire, with its capital in Constantinople (New Rome). Residents of the Empire, considered themselves Roman, or simply Christian. (Mango, Architettura Bizantina, 1974:9)

Traditional dates, the year 395 (the division of the Roman Empire by Theodosius) and 476 year (fall of the last Roman Emperor) are more symbolic than effective, for a specificity of eastern romanity. Indeed, the crisis of the third century, climbing to the throne of Diocletian (285) had ended unity of the Roman Empire, now governed by two or four August and Caesar. (Castellan, Histori e Ballkanit, 1991:34)

According to Norwich, Byzantium was a magical ringing words, as few other stories. That name will probably remain indelible in the memory of people musicality and images to arouse even today. Then the strategic location between East and West. And finally man: Constantine I, Emperor of Rome. This epochal Sovereign took two decisions that changed the course of history: the adoption of Christianity as the official religion of the empire and the transfer of the capital from Rome to a new city was built upon the ancient Byzantium, Constantinople. History of Byzantium starts with. (Norwich. J. J, Bizanti - Shkelqimi dhe renia e nje Perandorie, 2005:15)

But although never lost consciousness and his ties of old Rome, because ideally, for reasons of political interests of great power, constantly insisted Roman heritage. Byzantium nevertheless will leave more and more of the original characteristics of Roman civilization. In culture and language, Greece-isation progressed rapidly. At the same time church became a ubiquitous element of Byzantine life. Development and evaluation was also felt in the economic, social and political. Unlike what is commonly thought, the development of the Byzantine state was very dynamic. Movement, improvement, renovation were his features, as far as the end of its historical development, the Byzantine Empire was no longer anything in common with the old Roman Empire, except the name, traditions and aspirations unfeasible. (Ostrogorsky, Histori e Perandorise Bizantine, 2007:22)

Why study Byzantium? Even now, for most Europeans, except the Greeks, and other Eastern Orthodox tradition, 
his word Byzantium, makes you think of something exotic, and perhaps bureaucratic, corrupt. According to the Oxford English Reference Dictionary term "Byzantine" signifies something that is: a) extremely complex, b) or c fixed) that realized by means of secret. An anthropological work, Nupe tribe in Nigeria, based on field work done in 1930, used the title A Black Byzantium, apparently to show hierarchy, social stratification and complexity. (Cameron, Bizantinet, 2008:23) In Western European popular consciousness, the mention of Byzantium, promotes two main reactions: either he still thought of as irrelevant and outdated, predecessor of the Ottoman Empire and somehow involved in the religious and political problems of contemporary Balkan or mysteriously, seems to have a powerful attraction, as it is attached with icons and spirituality. (Guerdan, 1954) Each of these reactions, perseverance reveals the deep-rooted stereotypes that do not give what is due, or even Byzantine Greeks, as indeed exist. There is also a big difference between the perceptions that are Byzantines, Orthodox and non-Orthodox world, responding to the degree to which Byzantium, was the national story or not. (Cameron, Bizantinet, 2008:24)

\section{Religion in Byzantium}

The Byzantines were mystical and had blood Christ, St. Mary and the saints.(Norwich.J.J,2005:10)

With the division of the Roman Empire into two parts, between them showed significant differences in the way of religion and preaching. So the Byzantine churches language used was Greek, while in Western Europe, the language was Latin religious services. Were differences in the performance of religious ceremonies, fasting on Saturday, the use of bread in mass, in determining holy days, religious figures and rights to the clerics to marry or not.

It was again the Byzantine period, it gave the Church of the East, its character and location specific. First, by recognizing, on July 16, 1054, the division of the Christian Church, a Church under the Patriarch of the Byzantine East, detached from the Western Church under the Pope of Rome. This trend conflicts marking the completion of centuries, who tried in vain to mitigate the XIII and XIV centuries. On 1425, faced Pontifical delegate, a Byzantine dignitary said: "better to see the Turkish turban, in the middle of the capital, than Cardinal hat". (Castellan, Histori e Ballkanit,1991:37)

Since the mid-twelfth century, from Crusade II, we find a western fanatic. Langras Bishop, now dreams of taking Constantinople, and urges the king of France, Louis VII, which states that the Byzantines are "true Christian in name only", that they are guilty of heresy, and a large part the army of crusaders thought that "the Greeks were not Christians and had little to kill them." This antagonism was the result of a departure, which, from the IV century, was transformed into a large gap separator. As one side, and on the other were not agreed, especially Westerners, who, even knowing Greek disregarded. (Goff, 1998:173)

Since its origin, the church had been closely associated with the state, to the point that had precious basileusi it was his duty to intervene in matters of church discipline, even in the doctrine. Constantine convened the mind here Nikes (325) to determine Christian doctrine, and the role of emperors known in the fifth century Christological disputes, the struggle icons who did the shaking empire VIII and IX centuries, the crisis of the fourteenth century. (Castellan, Histori Ballkani, 1991:37)

So there was nothing like dualism pope - the emperor, who caused power conflicts as "Investiture war". There was a very strong symbiosis between the state and the church orthodox although not excluded personal conflicts. Patriarch intervene as imperial heritage issues as well as secular justice or the State University while under the archbishop and bishops often see themselves as leaders of the city, as Isidore of Thessalonica who defended the city against the Catalans. Church had taken over a part of the Byzantine State attributes. (Castellan, Histori Ballkani, 1991)

Christian Church as a spiritual force strength gains ever greater under Christian rule. In the early Byzantine emperor retains absolute authority over the Church, because, according to Roman tradition, considered trust of its citizens as part of jus publicum. But in medieval Byzantium Church wins in a significant political power by creating serious obstacles Emperor power. The fact is that even in Byzantium were often power struggles between the secular and the spiritual. Not always won these wars empire. But however in Byzantium is not characteristic tension between church and state but close and intimate connection between their progressive symbiosis between Orthodox and Orthodox state as a political organization - religious. Characteristic is the combination of interests and convergence of two factors and their conscious cooperation against any danger that threatened the theocratic rule of the empire, whether the threat came from enemies foreign or domestic Emperor, if it were the source of the corrupting effects heresies. But such a symbiosis puts inevitably Church under the tutelage of imperial power. Nevertheless this is typical and normal for the supremacy of the Byzantine emperor power versus power of the Church. (Ostrogorsky, Histori e Perandorise Bizantine, 2007:23)

The emperor is not only the supreme commander of the army, the highest judge and legislator alone, and he is the defender of the church and of the true faith. He is the chosen of God and as such is not only the head master of all but 
the living image of the Christian empire given in good faith from God. He is in direct relationship with God, he transcends the temporal and humanity, it is the object of a special cult politico - religious. Such a cult practiced every day in the yard under a suggestive ceremony in the church and attend all court. He said that every portrait is Christian emperor, in every object that surrounds his sacred person, in every word that he leads others and what others ask him. (Aifoldi, 1984:187)

\section{Byzantine art}

Byzantine art has been a criterion of importance. From the mid-nineteenth century, its success or failure, judged by the degree to which he was seen as a continuation of the classic tradition, identified with ancient Greece. Byzantine art, or not put it like that classic, or lauded as an image of the same tradition. (Spieser, 1991:338-362)

In the cultural field, the Eastern Roman Empire became Hellenic. Some modern Greek historian decide between VIII and IX centuries neohelenismit infancy, namely the use of the new Greek, detached from the language of Attica and set the "genesis of literature neohelenitike circa 1000". In fact, Greek was the language of the State and the Church and everything written in this language. Just Vlachs, nomadic shepherds, many in the highlands of Empire, speak dialects that come from Latin. (Castellan, Histori e Ballkanit, 1991:38)

Byzantine culture was seen to be based on two elements: Greek influence, classic, embodied for example in the education and teaching of rhetoric and Jewish and Christian traditions. Cyril Mango, Byzantine culture sees as an amalgam of the two, with a predominance of the latter, Christian influence. (Mango, Byzantium: The Empire of New Rome, 1980)

At the points of view, superstitious elements and medieval Byzantine culture are emphasized more strongly. Rather, Speros Vrionis mention this combination as "hybrid", and Byzantine culture as a culture of character "hybrid". (Vryonis, 1967:31)

Education elites dominated by the study of Greek rhetorical techniques. Specialized fields such as law, philosophy and theology receive a thorough motivation, which Magdalino Paul called "vital lubricant of all government machine". (Magdalino, 1993:336)

A large part of this preparation, skillful exercises standing in for classical themes or subjects, and was preceded by grammar, detailed study of old authors. His language was artificial high style, based on the style and vocabulary of the study authors, who were far from the Greek spoken at the time. In fact "imitation" was announced as a goal of education expressed in Byzantine and Byzantine literature. (H.Hunger, On the imitation of Antiquity in Byzantine litarature, 1969 70:17-38)

Much more than the study of Byzantine literature thriving history of Byzantine art in countries historically associated with religious and architectural heritage Byzantine scholars may often see it as part of its Orthodox tradition. (Barber, 2005:147-156). It has also been slow to focus its secession from the style and patronage. Esthetic evaluation, Byzantine art can actually be more difficult than that of Byzantine literature, because many people are drawn from Byzantine icons and Byzantine churches, without being aware that Byzantine art and architecture were also associated with contemporary conventions and played a special role in Byzantine society. Byzantine Art seduce directly as an art of beauty, luxury and spirituality, as indicated by the popularity of Byzantine exposures in Europe in recent years, especially the iconographic exhibition. (Cameron, Bizantinet, 2008:237)

Visual Arts in Byzantium were not excluded from this intellectual approach and classical. Even the artistic and literary production in this society dependent on patronage and concept artist was still crude, in addition, the relationship between patron and artist are something that usually does not have information. (Belting, Likeness and Presence: A History of the Image Before the Era of Art, 1994). Byzantine artists working environments embedded within technical and iconographic. Byzantine Icons born not far from personal inspiration and spontaneous painter often convey a message more complex iconographic and doctrinal. (Cameron, Bizantinet, 2008:207)

Byzantine pictures and medieval art and literature as it generally took place within religious topics. Feudal class and the clergy have used painting as a means to distract the masses from the real-world problems. They aimed to create the illusion believer of "a heavenly world" and hope to provoke the eternal life of heaven, which I really identify with human life. According to scholars, the Byzantine Divine contemplation achieved through sensual images. From this conceptual Esthetic principle derived propensity to everything that has gone on painting material. In Byzantine art Unreal principle triumphed. Requested by the artist within the strict rules and canons, which exclude his imagination, not reflected the real figures but the idea that lay at the basis of the ideal type, the unchanging essence expressing its metaphysical. Types iconographic tradition that recognizes, the prototype features portraits of Christ, the Virgin Mary and other saints and iconographic schemes in the process of developing more secular medieval art have changed quite small. 
That's why they are valuable human traits of living life as a true expression encountered rare but very meaningful and side of reflecting objective reality to these paintings conceived by religious mysticism. (Dhamo, 1974)

Byzantine visual culture had emerged from the rich visual culture of antiquity but is different from it, facing in the same time with the dilemmas of identity and well characterized reference Byzantine literature. Because of this ambiguity identity, some buildings dating is difficult: the so-called "ivory of Trier", for example, that reflects the achievement of memorabilia in Constantinople and their reception by the emperor, has been well established in the fifth century in the ninth. (Clanan, 2002: 24-26) Even Teodorës and Justinian mosaics in Ravenna room for disagreement even though in a narrower range. (McClanan, 2002:136)

\section{Byzantine architecture}

Religious buildings, being requested and completed their religion, well show different aspects of historical development, economic and social development and therefore their study is of great interest. (Meksi, 2004:7)

Important works of art with that known from centuries of medieval architecture belong. This is explained by the fact that the architecture was associated with everyday needs, housing, land protection, cult, and the needs of leading political forces of the time for monumental works.

Period of Justinian (527-565), was most intense in the area of construction, especially those of a military character. But there exist a civil constructions as waterworks, and profanity, as churches:

But there were only adornment that gave St. Sophia glow. Visitors see its architecture seemed magnificent. Greater sign of witchcraft constitute the cupola, an unprecedented height and width, a concave area with full forty windows on all sides, which made it seem "like hanging in the sky with a golden perch". (J. J. Norwich, Bizanti, 2005:69)

An important place among the monuments of medieval architecture, buildings occupied Christian worship. While apartments within castles were simple, Christian religious buildings consisted of large buildings, the basilica type or central plan. Basilicas were buildings that had a pronounced longitudinal stretch. They were divided into three main areas (naves) through a system pilastra or arcades on the columns and the roof covered with wooden lattice (Hellenistic version) or vault (Oriental version). On the eastern side was placed where the altar apse, while the main entrance from the west and was usually preceded by a parasallë (narthex). More rare are religious buildings with central plan. Their characteristic is building on a main environment located in the center of the building. Unlike basilicas in these constructions prevail against him longitudinal axis vertical. These buildings covered in most cases with a dome, are the basic features of Byzantine architecture. Other features of Byzantine ecclesiastical architecture: massive drums on which supports the dome, after painting the brick and rich conception of interior space that creates a sense of grandeur. (Historise, 2002:356-359)

History of Byzantium in 324 starts with the establishment of Constantinople and ends in 1453, with its conquest by Muslim Turks. According to this definition, Byzantine architecture, had a duration of 11 centuries, regardless of its survival after 1453 in many countries with Orthodox religion. In other words, monuments raised in this empire represent some common characteristics Byzantine and make readily distinguishable from some other cultures and styles as Romanico, Gotico or Islamico. After the seventh century or better after the ninth century, Byzantine architecture created a physiognomy that maintained itself until the end. While in previous centuries IV - VI is deeply ancient architecture even in the transformation process. There would be many reasons to establish a dividing line in the seventh century, to distinguish so early Christian architecture and Byzantine period precedent for the period ahead. With such a definition would leave out exactly Byzantine architecture during its first golden era Justiniana, "without St. Sophia Byzantine architecture is like a body without a head." But sometimes historical chronologies, do not coincide with architectural chronologies. (Mango, Architettura Bizantina, 1974:9)

Byzantium fell in 1453, but his spiritual tradition, and political, not disappeared. Faith, culture and Byzantine spiritual concept, continued to live exerting their influence, and riddled political and cultural life of the European peoples, whether in the former Byzantine territories beyond old if the empire. (Ostrogorsky, Histori e Perandorise Bizantine, 2007:451)

\section{References}

Aifoldi, A. (1934). Die Ausgestaltung des monarchischen Zeremonialls am romischen Kaiserhofen. (M. D. 49, Ed.),pg 187

Akademia e Shkencave e Shqiperise, Instituti i Historise, A. e. (2002). Historia e popullit Shqiptar. Tirane: Toena. pg 356- 359

Barber, C. (2005). Art History. (J. Harris, Ed.) Basingstoke: PalgraveAdvances in Byzantine History. pg 147-156 
Belting, H. (1994). Likeness and Presence: A History of the Image before the Era of Art. Chicago.

Cameron, A. (2008). Bizantinet. Tirane: Dituria. pg 23,24,31,207,237

Castellan, G. (1991). Histori e Ballkanit. Tirane: Cabej. pg 34,37,38

Clanan, A.M.(2002). Repressentations of Early Byzantine Empresses; Image and Empire. London.pg 24,26

Dhamo, D. (1974). Piktura murale e Mesjetes ne Shqiperi. Tirane: 8 Nentori.

Goff, J. L. (1998). Qyteterimi i Perendimit Mesjetar. Tirane: Toena.pg 173

Guerdan, R. (1954). Vie, grandeurs et miseres de Byzance. Paris.

H.Hunger. (1969 - 1970). On the imitation (mimesis)of antiquity in Byzantine literature. Dumbarton Oaks Paper 23-4. pg 17 - 38

Magdalino, P. (1993). The Empire of Manuel I Komnenos, 1143 - 1180. Cambridge. pg 336

Mango, C. (1974). Architettura Bizantina. Venezia: Electa Editrice. pg 9

Mango, C. (1980). Byzantium: The Empire of New Rome. London.

McClanan, A. (2002). Representations of Early Byzantine Empresses: Image and Empire. London.pg 136

Meksi, A. (2004). Arkitektura e kishave te Shqiperise. Tirane: Uegen. pg 7

Norwich,J. J. (2005). Bizanti - Shkelqimi dhe renia e nje Perandorie. Tirane: Uegen. pg 10,15,69

Ostrogorsky, G. (2007). Histori e Perandorise Bziantine. Tirane: Dituria. pg 22,23,451

Spieser, J. -M. (1991). Hellenisme et connaissance de l'art byzantin au XIXe siecle. (Said.S, Ed.) Leiden. pg 338-362

Vryonis, S. (1967). Byzantium and Europe. London.pg 31. 